\title{
Mobilization of hematopoietic progenitor cells for autologous transportation: consensus recommendations
}

\author{
Fernando Barroso Duarte ${ }^{*}$, Benedito de Pina Almeida Prado², Garles Miller Matias Vieira ${ }^{3}$, Luciano J. Costa \\ ${ }^{1}$ Service of Hematology and Hematopoietic Cell Transplantation - Hospital Universitário Walter Cantídio, Universidade Federal do Ceará, Brazil \\ ${ }^{2}$ Service of Apheresis of Centro Regional de Hemoterapia do HCFMRP-USP, Brazil \\ ${ }^{3}$ Department of Clinical Oncology and BMT Unit of AC Camargo Cancer Center, Brazil \\ ${ }^{4}$ Department of Medicine and UAB-CCC, Department of Bone Marrow Transplantation and Cell Therapy Program, Birmingham, AL, USA
}

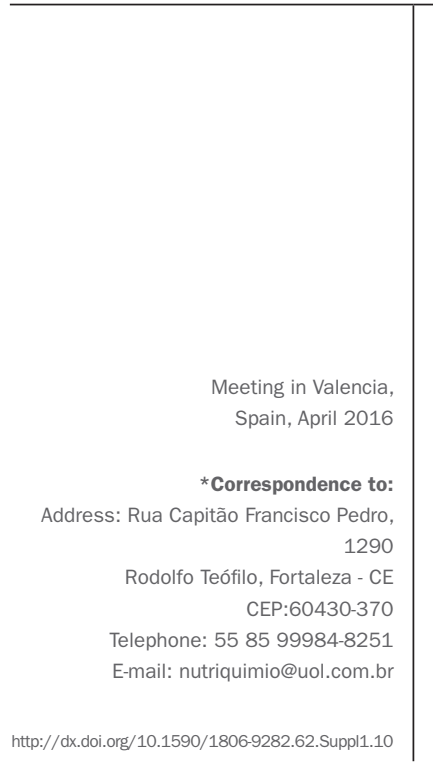

\section{SUMMARY}

Selected patients with certain hematological malignancies and solid tumors have the potential to achieve long-term survival with autologous hematopoietic progenitor cell transplant. The collection of these cells in peripheral blood avoids multiple bone marrow aspirations, results in faster engraftment and allows treatment of patients with infection, fibrosis, or bone marrow hypocellularity. However, for the procedure to be successful, it is essential to mobilize a sufficient number of progenitor cells from the bone marrow into the blood circulation. Therefore, a group of Brazilian experts met in order to develop recommendations for mobilization strategies adapted to the reality of the Brazilian national health system, which could help minimize the risk of failure, reduce toxicity and improve the allocation of financial resources.

Keywords: Hematopoietic stem cell mobilization; Autologous transplantation; Plerixafor; G-CSF

\section{INTRODUCTION}

Autologous transplantation of hematopoietic progenitor cells from peripheral blood is a well-established therapy for some hematological malignancies, such as multiple myeloma, non-Hodgkin's and Hodgkin's lymphoma, as well as for some solid neoplasms, such as germ cell tumors. ${ }^{1,2}$ Mobilization and collection are crucial steps in this procedure, which aim not only at obtaining enough stem cells for transplantation but also at minimizing the number of apheresis sessions, reducing the risk of complications, preventing failure and optimizing resource allocation. ${ }^{3}$ The choice of the mobilization regimen should take into account factors such as efficacy, safety, convenience and cost-effectiveness. ${ }^{4}$ Even though they are well established in everyday practice of Hematology and Transplant centers, mobilization regimens can vary greatly from one institution to another and differ in terms of clinical and pharmacoeconomic outcomes. ${ }^{5-7}$

Of the currently available regimens, the one most commonly used involves the isolated use of the granulocyte-colony stimulating factor (G-CSF), which has the advantages of being well tolerated and allowing the programming of apheresis procedures. ${ }^{8,9}$ The combination of chemotherapy and G-CSF has shown to improve the collection of CD34 + cells and reduce tumor activity, but at the expense of increased risk of complications such as fever and neutropenia. In turn, the combination of G-CSF and plerixafor has been shown to result in reduced risk of mobilization failure, improves the collection of CD34 + cells and a favorable tolerability profile, but at a higher cost.

Thus, the combination of G-CSF and plerixafor has been used as the initial regimen for patients with risk factors for poor mobilization, preemptively in patients with early signs of mobilization failure, as well as a rescue strategy in cases of failed mobilization with other regimens. ${ }^{9-12}$ Other currently available rescue strategies include the re-mobilization with the same regimen used previously, the segmentation of the G-CSF doses and collection of cells directly from bone marrow. ${ }^{13}$

Recently, the American Society for Blood and Marrow Transplantation ${ }^{4}$ and a panel of US experts ${ }^{3}$ published their guidelines and recommendations to optimize the mobilization of hematopoietic stem cells from peripheral blood. Considering the peculiarities of the Brazilian public health system and the need for more standardized approaches in our country, a panel of national experts was summoned to meet and develop consensus recommendations adapted 
to our reality and that could serve as a starting point for broader efforts to improve clinical outcomes of patients submitted to autologous hematopoietic stem cell transplantation from peripheral blood in Brazil.

\section{Predictive factors OF POOR MOBILIzation}

The identification of risk factors associated with the disease and the patient that can predict poor mobilization of hematopoietic progenitor cells is of utmost importance for the optimization of both the therapy and resource allocation. Several studies carried out to investigate this question showed that the diagnosis of lymphoma, ${ }^{14-19}$ thrombocytopenia, ${ }^{14,20-23}$ older age ${ }^{18-21,23-25}$ and polytreatment $^{14,16,19,25,26}$, among other factors, emerged as the main potential factors for the prediction of poor recruitment of hematopoietic stem cells.

However, the retrospective characteristic of these studies, the relatively low number of assessed patients, the heterogeneity of the studied populations, the use of different mobilization regimens and lack of uniform criteria for the definition of failure contributed to the achievement of conflicting results, ${ }^{11,27-29}$ making data interpretation and the drawing of definitive conclusions about the role of these factors in therapeutic decision-making difficult. The most robust factor for the prediction of collection efficiency is the CD34+ cell count in peripheral blood before apheresis and its implementation in daily practice has the added potential to save financial resources. ${ }^{7,30-34}$

Recommendation: the isolated use of pre-treatment clinical and laboratory factors to identify patients at risk of poor mobilization and to select the best therapeutic approach shows conflicting results in the literature. However, potentially more effective mobilization strategies - such as chemo-mobilization and plerixafor-based regimens should be considered for patients who have these factors. A low number of CD34+ cells in peripheral blood before apheresis is the most robust predictor of collection failure; thus, the cell count should be performed in all patients submitted to autologous transplantation of hematopoietic progenitor cells.

\section{Measurement of CD34+ CELL COUNT IN PERIPHERAL BLOOD}

The use of flow cytometry for CD34 + cell count in peripheral blood has become a standard technique to evaluate the recruitment of these progenitor cells and to optimize mobilization strategies, ${ }^{3,4,7}$ having been implemented in the routine practice in the vast majority of treatment centers. ${ }^{35,36}$ Although several methodologies and cytometric assays have been described, there can be great variability among the observed cell counts and the lack of standardized methods has led to the obtaining of widely differing results. ${ }^{35,37}$ The sample type and condition, the used reagent and the characteristics of the employed anti-CD34 monoclonal antibodies are some potential error sources for the cytofluorimetric measurement of CD34 + cell count. ${ }^{38}$

The three main techniques of hematopoietic progenitor cell count include the Milan/Mullhouse two-platform protocol and the two-platform and single-platform analysis systems of ISHAGE (International Society of Hematotherapy and Graft Engineering). In the two-platform method, the percentage of CD34 + cells is determined by flow cytometry and the leukocyte count is performed in an automated hematology analyzer. The development of single-platform methods allowed the absolute count of $\mathrm{CD} 34+$ cells through a single device - the flow cytometer. ${ }^{39}$ The results obtained with the three methods are apparently comparable, with a low rate of divergence..$^{39,40}$ Given their presumed interchangeability, the choice between these three methods can be based on subjective criteria, such as convenience, cost, and simplicity. ${ }^{39}$

Recommendation: the exact quantification of $\mathrm{CD} 4+$ cells in peripheral blood is currently a highly relevant factor for a successful autologous hematopoietic stem cell transplantation. The purchase notices of kits for the analysis of this parameter should be carefully prepared, aiming at the acquisition of accurate, reliable products that have been submitted to quality control testing.

\section{Mobilization With G-CSF}

G-CSF is the most commonly used mobilizing agent, either alone or in combination with chemotherapy. The generally applied dose is $10 \mu \mathrm{g} / \mathrm{kg}$ subcutaneously, with apheresis being started on the fifth or sixth day, until the number of target cells is achieved. ${ }^{41,42}$ Some studies postulated that G-CSF dose division could result in better mobilization. The pharmacological profile of G-CSF demonstrates a maximum serum concentration within 2 to 8 hours after subcutaneous administration. ${ }^{43}$

Considering an elimination half-life of 3 to 4 hours, the dose division could result in higher basal serum concentrations and, consequently, better mobilization. ${ }^{44}$ However, studies comparing a single daily dose versus divided dose of G-CSF showed conflicting results. ${ }^{5,44}$ Higher doses of G-CSF ( 8 to $12 \mu \mathrm{g} / \mathrm{kg} / 12 \mathrm{~h}$ ) resulted in the collection of a higher number of CD34 + cells with fewer apheresis procedures, suggesting the existence of a dose-effect response. . $^{4-47}$

The use of G-CSF has the advantage of allowing the mobilization planning, resulting in more predictability, 
when compared to chemotherapy. Moreover, G-CSF can be administered at home, resulting in greater convenience for patients. G-CSF also has a favorable toxicity profile, with the most frequent adverse events being mild to moderate musculoskeletal pain (usually controlled with conventional analgesics), as well as dysuria, fever, headache, nausea and asymptomatic increase in alkaline phosphatase and gamma-glutamyl transferase. ${ }^{48,49}$ Retrospective and prospective randomized studies suggest that the granulocyte-monocyte colony stimulating factor (GM-CSF) is less effective than G-CSF in mobilizing hematopoietic progenitor cells, either alone or in combination with chemotherapy, with an additional less favorable profile of safety and tolerability. ${ }^{48,50}$ The combination of G-CSF and GM-CSF did not result in significant clinical benefits in comparison with isolated G-CSF. ${ }^{51}$ Pegfilgrastim has not been widely accepted by transplant centers, due to the fact that G-CSF is easy to use and the accumulated experience using it, as well as cost-related matters. ${ }^{42}$

Recommendation: G-CSF can be used alone to mobilize hematopoietic progenitor cells at doses of 10 to $20 \mu \mathrm{g} / \mathrm{kg}$, divided into 2 to 4 equal daily applications, or with a higher dose in the morning.

\section{Chemomobilization}

The decision between mobilization with G-CSF alone or a combination of chemotherapy and G-CSF should take into account factors such as the remission status of the underlying disease and the probability of poor mobilization. ${ }^{52}$ The combination of G-CSF with chemotherapy accomplishes the double purpose of promoting both the mobilization of hematopoietic progenitor cells and the reduction of antitumor activity, with the latter effect being demonstrated in cases of lymphoma and also of multiple myeloma. Moreover, the combination of chemotherapy and G-CSF has the advantage of resulting in the collection of a higher number of $\mathrm{CD} 34+$ cells and requiring fewer apheresis procedures, when compared with the isolated use of G-CSF. In contrast, chemomobilization is associated with lower predictability to the start of apheresis, as well as the toxicity and complications from the chemotherapy regimen used, including febrile neutropenia and need for hospitalization. ${ }^{10,42,50,52}$ Moreover, when the chemomobilization is used as a cycle of part of the induction or rescue therapy, additional expenses with the chemotherapy itself and also hospitalization for treatment administration and management of complications result in higher costs related to the isolated use of G-CSF. ${ }^{6}$

The combination of G-CSF with high-doses cyclophosphamide was shown to improve the efficiency of col- lection and increase the correlation between the CD34+ cell counts in peripheral blood and in the final collection. ${ }^{8,49}$ Etoposide, in turn, has shown to be effective in the treatment of Hodgkin's and non-Hodgkin's lymphoma; thus, its inclusion in the mobilization regimens of patients with these tumors has the advantage of providing treatment during the mobilization phase ${ }^{49}$. The combination of vinorelbine and G-CSF is an excellent alternative in comparison with G-CSF alone or in combination with cyclophosphamide, showing a more favorable toxicity profile, resulting in earlier collection and lower costs. Furthermore, outpatient administration with one in bolus injection and better predictability of apheresis improve patient comfort and simplify the collection procedure, both in multiple myeloma and in malignant lymphoma..$^{53-55}$

The use of several cytotoxic combination regimes have also been described, including cisplatin, cytosine arabinoside, dexamethasone (DHAP); ifosfamide, carboplatin and etoposide (ICE); etoposide, methylprednisolone, cytarabine and cisplatin (ESHAP); cyclophosphamide, mitoxantrone, dexamethasone (CMD); dexamethasone, carmustine, etoposide, cytarabine, melphalan (DexaBEAM); ifosfamide, epirubicin, etoposide (IEE); cyclophosphamide and etoposide with or without cisplatin; and etoposide and rituximab. ${ }^{8}$

Recommendation: mobilization with chemotherapy combined with G-CSF (beginning on the day after completion of chemotherapy) can be performed with cyclophosphamide 2 to $3 \mathrm{~g} / \mathrm{m}^{2}$ or vinorelbine $35 \mathrm{mg} / \mathrm{m}^{2}$ in a single dose ${ }^{61}$ or etoposide $375 \mathrm{mg}$. The selection of other chemomobilization regimens should preferably take into account the sensitivity of the underlying malignancy to the different cytotoxic agents.

\section{Mobilization WITH PLERIXAfOR}

Plerixafor is a reversible antagonist of chemokine receptor type 4 (CXCR4), which blocks the interaction between the receptor and its ligand - the CXC chemokine type 12 - and causes the release of CD34+ cells from the bone marrow into blood circulation. The efficacy and tolerability of the combination of Plerixafor and G-CSF in promoting the mobilization of progenitor cells in patients with previous failed mobilization attempts has been demonstrated in several prospective trials, with success rates ranging from 60 to $90 \%$, even among patients aged $\geq 60$ years.

Furthermore, the combination of Plerixafor and G-CSF has also been successfully used in patients with poor mobilization risk factors. Compared to chemomobilization, the combination of Plerixafor and G-CSF provides 
greater predictability of the time to obtain CD34+ cell count peak, resulting in improved collection efficiency and fewer apheresis sessions. In the absence of a clear chemotherapy indication, the combination of Plerixafor and G-CSF may be preferred to chemomobilization in patients at high risk of failure. On the other hand, only one formal phase II study on the combination of plerixafor, chemotherapy and G-CSF has been published to date, so that the evidence for the use of this regimen is scarce. ${ }^{10,56,57}$

Plerixafor can also be used preemptively in patients with early signs of poor mobilization, even in the absence of known risk factors. Several algorithms have been developed to guide the preemptive use of plerixafor. Evidence indicates that the number of collections and failure rates can be substantially reduced with the use of this strategy, although a group of patients may still develop with poor mobilization. In patients undergoing mobilization with G-CSF alone, the decision to preemptively add plerixafor usually occurs after 4 days of the mobilization onset and depends on the target for collection. Usually, the addition of plerixafor is indicated for patients with CD34+ cell count $<10 / \mathrm{mm}^{3}$ on day +4 . This strategy has been shown to result in similar or lower total costs compared to traditional mobilization methods, when taking into account the management of adverse events and complications associated with alternative regimens of mobilization and mobilization failure. $^{56-58}$

Recommendation: plerixafor, at a dose of $240 \mathrm{mg} / \mathrm{kg}$ subcutaneously, should be preemptively administered in patients undergoing mobilization with G-CSF and $<10$ $\mathrm{CD} 34+$ cells per $\mathrm{mm}^{3}$ at day +5 , between 6 and 11 hours before apheresis. Patients showing failure mobilization with chemotherapy and G-CSF are also candidates for rescue with plerixafor and G-CSF. There are no conclusive data for the use of chemotherapy in combination with plerixafor.

\section{MobiLization faILURE APPROACHES}

G-CSF, alone or in combination with chemotherapy is still the most common approach to mobilize hematopoietic progenitor cells for autologous transplantation candidates. Considering that a proportion of patients have insufficient mobilization and are therefore deprived of the transplantation benefit, at least at a first moment, the costs associated with failure are many, including the inconvenience and the psychological impact of mobilization failure on the patient, in addition to the costs of morbidity and mortality associated with subsequent attempts at mobilization. Therefore, strategies are crucial to minimize the risks of failure at the second or third mobilization. Options for remobilization include dividing the G-CSF dose, remobilization with chemotherapy and G-CSF, remobilization with the same previous regimen, the combination of plerixafor and G-CSF and bone marrow collection. . $^{10,42,59}$

Mobilization failures are generally defined as $<2 * 106$ $\mathrm{CD} 34+$ cells collected per $\mathrm{kg}$ in a single mobilization or more than 4 sessions of apheresis to collect this minimum number of cells. ${ }^{10}$ The division of the G-CSF dose seems to be effective in approximately $1 / 3$ of the patients; however, confirmatory data regarding the effectiveness of this strategy are scarce. ${ }^{60}$ Evidence from different centers suggest that remobilization with the combination of intensive chemotherapy and growth factor may result in an increase in the number of progenitor cells in patients with poor pre-mobilization; however, the benefit of this strategy must be weighed against its toxicity and cost. For cases in which the mobilization has been performed earlier - before complete recovery from the previous chemotherapy - and mobilization is poor, a second mobilization with the same regimen may be useful. Regarding the combination of plerixafor and G-CSF, this strategy is more likely to be successful than other rescue strategies ${ }^{0}$, allowing obtaining the target CD34+ cell count in $>70 \%$ of cases. Finally, isolated reports seem to indicate that the addition of bone marrow cells to peripheral blood progenitor cells may benefit patients with poor mobilization. ${ }^{10,42,59}$

Recommendation: in cases of mobilization failure, it is recommended to allow at least 3 weeks for recovery before a new attempt, particularly in cases of unsuccessful chemomobilization. In cases of failure with G-CSF alone, it is recommended to carry out the remobilization by dividing the G-CSF dose, or chemomobilization. In case of chemomobilization failure, it is recommended to carry out the remobilization with plerixafor and G-CSF, or with the growth factor alone. In case of failure using plerixafor and $G-C S F$, remobilization is recommended using the same strategy, or to perform bone marrow collection.

\section{Conclusions}

The presence of risk factors for poor mobilization should be carefully investigated and it may have an impact on the selection of the most appropriate mobilization regimen. The counting of the number of $\mathrm{CD} 34+$ cells in peripheral blood should be performed prior to apheresis in all patients submitted to autologous hematopoietic stem cell transplantation through an accurate and reliable laboratory test, of which quality is controlled. Patients with cell count $<10 \mathrm{CD} 34+$ cells per $\mathrm{mm}^{3}$ on day +5 are candidates for the preemptive use of plerixafor in combination with G-CSF. The selection of other mobilization regimens 
should take into account efficacy, safety, convenience and cost-effectiveness. Algorithms to minimize mobilization failure risks should be used to reduce complications and additional costs associated with treatment failure.

In cases of poor mobilization (collection resulting in $<2 * 106 \mathrm{CD} 34+$ cells per $\mathrm{kg}$, in a single mobilization or $>4$ apheresis sessions), remobilization strategies should also take into account the previously used system. Pharmacoeconomic evaluations should include not only the cost of drugs, but also resource savings associated with the reduction in the number of apheresis sessions, complications of treatment, need for hospitalization, mobilization failure risks, as well as morbidity and mortality associated to remobilization.

\section{Resumo}

Mobilização de células progenitoras hematopoéticas para transplante autólogo: recomendações de consenso

Pacientes selecionados com certas neoplasias hematológicas e tumores sólidos têm o potencial de alcançar sobrevida de longo prazo com o transplante autólogo de células progenitoras hematopoéticas. A coleta dessas células no sangue periférico evita múltiplas aspirações de medula óssea, resulta em enxertia mais rápida, e permite o tratamento de pacientes com infiltração, fibrose ou hipocelularidade medular. Contudo, para o sucesso desse procedimento, é essencial mobilizar um número suficiente de células progenitoras da medula óssea para a circulação sanguínea. Por isso, um painel de especialistas brasileiros se reuniu com o objetivo de desenvolver recomendações para estratégias de mobilização adaptadas à realidade do sistema de saúde nacional, que pudessem contribuir para minimizar os riscos de falha, reduzir a toxicidade e melhorar a alocação de recursos financeiros.

Palavras-chave: Mobilização de células-tronco hematopoéticas; Transplante autólogo; Plerixafor; G-CSF.

\section{References}

1. Muller AM, Ihorst G, Waller CF, Dölken G, Finke J, Engelhardt M. Intensive chemotherapy with autologous peripheral blood stem cell transplantation during a 10-year period in 64 patients with germ cell tumor. Biol Blood Marrow Transplant. 2006;12(3):355-65.

2. Jantunen E, Varmavuo V. Plerixafor for mobilization of blood stem cells in autologous transplantation: an update. Expert Opin Biol Ther. 2014;14(6):851-61.

3. Giralt S, Costa L, Schriber J, Dipersio J, Maziarz R, McCarty J, et al., Optimizing autologous stem cell mobilization strategies to improve patient outcomes: consensus guidelines and recommendations. Biol Blood Marrow Transplant. 2014;20(3):295-308.

4. Duong HK, Savani BN, Copelan E, Devine S, Costa LJ, Wingard JR, et al. Peripheral blood progenitor cell mobilization for autologous and allogeneic hematopoietic cell transplantation: guidelines from the American Society for Blood and Marrow Transplantation. Biol Blood Marrow Transplant. 2014; 20(9):1262-73.
5. Carrion R, Serrano D, Gómez-Pineda A, Díez-Martín JL. A randomised study of $10 \mathrm{microg} / \mathrm{kg} /$ day (single dose) vs 2 x 5 microg $/ \mathrm{kg} /$ day (split dose) G-CSF as stem cell mobilisation regimen in high-risk breast cancer patients. Bone Marrow Transplant. 2003;32(6):563-7.

6. Shaughnessy P, Chao N, Shapiro J, Walters K, McCarty J, Abhyankar S, et al Pharmacoeconomics of hematopoietic stem cell mobilization: an overview of current evidence and gaps in the literature. Biol Blood Marrow Transplant. 2013;19(9):1301-9.

7. Mohty M, Hübel K, Kröger N, Aljurf M, Apperley J, Basak GW, et al Autologous haematopoietic stem cell mobilisation in multiple myeloma and lymphoma patients: a position statement from the European Group for Blood and Marrow Transplantation. Bone Marrow Transplant. 2014;49(7):865-72.

8. Sheppard D, Bredeson C, Allan D, Tay J. Systematic review of randomized controlled trials of hematopoietic stem cell mobilization strategies for autologous transplantation for hematologic malignancies. Biol Blood Marrow Transplant. 2012; 18(8):1191-203.

9. Wood WA, Whitley J, Goyal R, Brown PM, Sharf A, Irons R, et al., Effectiveness of etoposide chemomobilization in lymphoma patients undergoing auto-SCT. Bone Marrow Transplant. 2013;48(6):771-6.

10. Tanhehco YC, Vogl DT, Stadtmauer EA, O'Doherty U. The evolving role of plerixafor in hematopoietic progenitor cell mobilization. Transfusion. 2013;53(10):2314-26.

11. Costa LJ, Nista EJ, Buadi FK, Lacy MQ, Dispenzieri A, Kramer CP, et al. Prediction of poor mobilization of autologous CD34+ cells with growth factor in multiple myeloma patients: implications for risk-stratification. Biol Blood Marrow Transplant. 2014;20(2):222-8.

12. Milone G, Martino M, Spadaro A, Leotta S, Di Marco A, Scalzulli P, et al. Plerixafor on-demand combined with chemotherapy and granulocyte colony-stimulating factor: significant improvement in peripheral blood stem cells mobilization and harvest with no increase in costs. Br J Haematol. 2014;164(1):113-23.

13. Stiff PJ. Management strategies for the hard-to-mobilize patient. Bone Marrow Transplant. 1999;23(Suppl 2): S29-33.

14. Mendrone A Jr, Arrais CA, Saboya R, Chamone Dde A, Dulley FL. Factors affecting hematopoietic progenitor cell mobilization: an analysis of 307 patients. Transfus Apher Sci. 2008;39(3):187-92.

15. Ozkurt ZN, Yegin ZA, Suyani E, Aki SZ, Acar K, Yagci M, et al. Factors affecting stem cell mobilization for autologous hematopoietic stem cell transplantation. J Clin Apher. 2010;25(5):280-6.

16. Sancho JM, Morgades M, Grifols JR, Juncà J, Guardia R, Vives S, et al Predictive factors for poor peripheral blood stem cell mobilization and peak CD34(+) cell count to guide pre-emptive or immediate rescue mobilization. Cytotherapy. 2012;14(7):823-9.

17. Ungerstedt JS, Watz E, Uttervall K, Johansson BM, Wahlin BE, Näsman P, et al. Autologous hematopoietic stem cell transplantation in multiple myeloma and lymphoma: an analysis of factors influencing stem cell collection and hematological recovery. Med Oncol. 2012;29(3):2191-9.

18. Donmez A, Yilmaz F, Gokmen N, Tombuloglu M. Risk factors for a poor hematopoietic stem cell mobilization. Transfus Apher Sci. 2013;49(3):485-8.

19. Kurnaz F,Kaynar L. Peripheral blood stem cell mobilization failure. Transfus Apher Sci. 2015;53(1):3-7.

20. Akhtar S, Weshi AE, Rahal M, Khafaga Y, Tbakhi A, Humaidan H, et al. Factors affecting autologous peripheral blood stem cell collection in patients with relapsed or refractory diffuse large cell lymphoma and Hodgkin lymphoma: a single institution result of 168 patients. Leuk Lymphoma. 2008;49(4):769-78.

21. Lacativa CP, Lacativa PG, Garnica M, Portugal RD, Schaffel R, Dutra Hdos S, et al. Risk factors for unsuccessful peripheral blood stem cell harvesting using granulocyte-colony stimulating factor mobilization in patients with multiple myeloma. Transfus Apher Sci. 2012;47(3):331-5.

22. Demiriz IS, Bozdağ SC, Tekgündüz E, Uğur B, Durgun G, Koçubaba S, et al Predicting the successful peripheral blood stem cell harvesting. Transfus Apher Sci. 2013;48(3):411-4

23. Pozotrigo M, Adel N, Landau H, Lesokhin A, Lendvai N, Chung DJ, Chimento $\mathrm{D}$, et al. Factors impacting stem cell mobilization failure rate and efficiency in multiple myeloma in the era of novel therapies: experience at Memorial Sloan Kettering Cancer Center. Bone Marrow Transplant. 2013;48(8):1033-9.

24. Gabus R, Borelli G, Ferrando M, Bódega E, Citrín E, Jiménez CO, et al. Mobilization of hematopoietic progenitor cells with granulocyte colony stimulating factors for autologous transplant in hematologic malignancies: a single center experience. Rev Bras Hematol Hemoter. 2011;33(6):410-6.

25. Xia W, Ma CK, Reid C, Bai L, Wong K, Kerridge ,et al. Factors determining pbsc mobilization efficiency and nonmobilization following ICE with or without rituximab (R-ICE) salvage therapy for refractory or relapsed lymphoma prior to autologous transplantation. J Clin Apher. 2014;29(6):322-30.

26. Wuchter P, Ran D, Bruckner T, Schmitt T, Witzens-Harig M, Neben K, Goldschmidt $\mathrm{H}$, et al. Poor mobilization of hematopoietic stem cells-definitions, incidence, risk factors, and impact on outcome of autologous transplantation. Biol Blood Marrow Transplant. 2010;16(4):490-9.

27. Kotasek D, Shepherd KM, Sage RE, Dale BM, Norman JE, Charles P, et al Factors affecting blood stem cell collections following high-dose cyclophosphamide mobilization in lymphoma, myeloma and solid tumors. Bone Marrow Transplant. 1992;9(1):11-7. 
28. Weaver CH, Schwartzberg LS, Birch R, Greco FA, Rhinehart S, Hainsworth $\mathrm{J}$, et al. Collection of peripheral blood progenitor cells after the administration of cyclophosphamide, etoposide, and granulocyte-colony-stimulating factor: an analysis of 497 patients. Transfusion. 1997;37(9):896-903.

29. Vantelon JM, Koscielny S, Brault P, Bourhis JH, Ribrag V, Pico J, et al. Scoring system for the prediction of successful peripheral blood stem cell (PBSC) collection in non-Hodgkin's lymphoma (NHL): application in clinical practice. Bone Marrow Transplant. 2000;25(5):495-9.

30. Fontao-Wendel R, Lazar A, Melges S, Altobeli C, Wendel S. The absolute number of circulating CD34+ cells as the best predictor of peripheral hematopoietic stem cell yield. J Hematother. 1999; 8(3):255-62.

31. Ford CD, Chan KJ, Reilly WF, Petersen FB. An evaluation of predictive factors for CD34+ cell harvest yields from patients mobilized with chemotherapy and growth factors. Transfusion. 2003;43(5):622-5.

32. Basquiera AL, Abichain P, Damonte JC, Ricchi B, Sturich AG, Palazzo ED, et al. The number of CD34(+) cells in peripheral blood as a predictor of the $\mathrm{CD} 34(+)$ yield in patients going to autologous stem cell transplantation. J Clin Apher. 2006;21(2):92-5.

33. Meehan KR, Hill JM, Patchett L, Webber SM, Wu J, Ely P, et al. Implementation of peripheral blood CD34 analyses to initiate leukapheresis: marked reduction in resource utilization. Transfusion. 2006;46(4):523-9.

34. Rossi G, Skert C, Morello E, Almici C, Arcaini L, Basilico C, et al. PBSC mobilization in lymphoma patients: analysis of risk factors for collection failure and development of a predictive score based on the kinetics of circulating CD34+ cells and WBC after chemotherapy and G-CSF mobilization. Hematol Oncol. 2015;33(3):125-32.

35. Gratama JW, Orfao A, Barnett D, Brando B, Huber A, Janossy G, et al. Flow cytometric enumeration of CD34+ hematopoietic stem and progenitor cells. European Working Group on Clinical Cell Analysis. Cytometry. 1998;34(3):128-42.

36. Whitby A, Whitby L, Fletcher M, Reilly JT, Sutherland DR, Keeney M, et al. ISHAGE protocol: are we doing it correctly? Cytometry B Clin Cytom. 2012;82(1):9-17.

37. Sutherland DR, Anderson L, Keeney M, Nayar R, Chin-Yee I. The ISHAGE guidelines for CD34+ cell determination by flow cytometry. International Society of Hematotherapy and Graft Engineering. J Hematother. 1996;5(3):213-26.

38. Basso G, Timeu F. Cytofluorimetric analysis of CD34 cells. Bone Marrow Transplant. 1998;22(Suppl 5):S17-20.

39. Gajkowska A Oldak T, Jastrzewska M, Machaj EK, Walewski J, Kraszewska E, et al. Flow cytometric enumeration of CD34+ hematopoietic stem and progenitor cells in leukapheresis product and bone marrow for clinical transplantation: a comparison of three methods. Folia Histochem Cytobiol. 2006;44(1):53-60.

40. Keeney M, Chin-Yee I, Weir K, Popma J, Nayar R, Sutherland DR. Single platform flow cytometric absolute CD34+ cell counts based on the ISHAGE guidelines. International Society of Hematotherapy and Graft Engineering. Cytometry. 1998;34(2):61-70.

41. Hoggatt J, Speth JM, Pelus LM. Concise review: sowing the seeds of a fruitful harvest: hematopoietic stem cell mobilization. Stem Cells. 2013;31(12):2599-606.

42. Goker H, Etgul S, Buyukasik Y. Optimizing mobilization strategies in difficult-to-mobilize patients: the role of plerixafor. Transfus Apher Sci. 2015;53(1):23-9.

43. de Haas M, Kerst JM, van der Schoot CE, Calafat J, Hack CE, Nuijens JH, et al. Granulocyte colony-stimulating factor administration to healthy volunteers: analysis of the immediate activating effects on circulating neutrophils. Blood. 1994;84(11):3885-94

44. Kroger N, Zeller W, Hassan HT, Krüger W, Gutensohn K, Löliger C, et al. Stem cell mobilization with G-CSF alone in breast cancer patients: higher progenitor cell yield by delivering divided doses $(2 \times 5 \mathrm{microg} / \mathrm{kg})$ compared to a single dose ( 1 x $10 \mathrm{microg} / \mathrm{kg})$. Bone Marrow Transplant. 1999; 23(2):125-9.
45. Sheridan WP, Begley CG, To LB, Grigg A, Szer J, Maher D, et al. Phase II study of autologous filgrastim (G-CSF)-mobilized peripheral blood progenitor cells to restore hemopoiesis after high-dose chemotherapy for lymphoid malignancies. Bone Marrow Transplant. 1994;14(1):105-11.

46. Zeller W, Gutensohn K, Stockschläder M, Dierlamm J, Kröger N, Koehne G, et al. Increase of mobilized CD34-positive peripheral blood progenitor cells in patients with Hodgkin's disease, non-Hodgkin's lymphoma, and cancer of the testis. Bone Marrow Transplant. 1996;17(5):709-13.

47. Demirer T, Ayli M, Ozcan M, Gunel N, Haznedar R, Dagli M, et al Mobilization of peripheral blood stem cells with chemotherapy and recombinant human granulocyte colony-stimulating factor (rhG-CSF): a randomized evaluation of different doses of rhG-CSF. Br J Haematol 2002:116(2):468-74

48. Siena S, Bregni M, Gianni AM. Mobilization of peripheral blood progenitor cells for autografting: chemotherapy and G-CSF or GM-CSF. Baillieres Best Pract Res Clin Haematol. 1999;12(1-2):27-39.

49. Rosenbeck LL, Srivastava S, Kiel PJ. Peripheral blood stem cell mobilization tactics. Ann Pharmacother. 2010;44(1):107-16.

50. Martino M, Laszlo D, Lanza F. Long-active granulocyte colony-stimulating factor for peripheral blood hematopoietic progenitor cell mobilization. Expert Opin Biol Ther. 2014;14(6):757-72

51. Spitzer G, Adkins D, Mathews M, Velasquez W, Bowers C, Dunphy F, et al Randomized comparison of G-CSF + GM-CSF vs G-CSF alone for mobilization of peripheral blood stem cells: effects on hematopoietic recovery after high-dose chemotherapy. Bone Marrow Transplant. 1997;20(11):921-30.

52. Kindwall-Keller T. Peripheral stem cell collection: from leukocyte growth factor to removal of catheter. J Clin Apher. 2014;29(4):199-205.

53. Bargetzi MJ, Passweg J, Baertschi E, Schoenenberger A, Gwerder C, Tichelli A, et al. Mobilization of peripheral blood progenitor cells with vinorelbine and granulocyte colony-stimulating factor in multiple myeloma patients is reliable and cost effective. Bone Marrow Transplant. 2003;31(2):99-103.

54. Heizmann M, O'Meara AC, Moosmann PR, Heijnen IA, Zuberbühler M, Fernandez P, et al. Efficient mobilization of PBSC with vinorelbine/GCSF in patients with malignant lymphoma. Bone Marrow Transplant. 2009;44(2):75-9.

55. Samaras P, Pfrommer S, Seifert B, Petrausch U, Mischo A, Schmidt A, et al. Efficacy of vinorelbine plus granulocyte colony-stimulation factor for $\mathrm{CD} 34+$ hematopoietic progenitor cell mobilization in patients with multiple myeloma. Biol Blood Marrow Transplant. 2015;21(1):74-80.

56. Dugan MJ, Maziarz RT, Bensinger WI, Nademanee A, Liesveld J, Badel K, et al. Safety and preliminary efficacy of plerixafor (Mozobil) in combination with chemotherapy and G-CSF: an open-label, multicenter, exploratory trial in patients with multiple myeloma and non-Hodgkin's lymphoma undergoing stem cell mobilization. Bone Marrow Transplant. 2010;45(1):39-47.

57. Fruehauf S. Current clinical indications for plerixafor. Transfus Med Hemother. 2013;40(4):246-50

58. Costa LJ, et al. Growth factor and patient-adapted use of plerixafor is superior to $\mathrm{CY}$ and growth factor for autologous hematopoietic stem cells mobilization. Bone Marrow Transplant. 2011;46(4):523-8.

59. Herbert KE, Levesque JP, Mills AK, Gottlieb DJ, Cooney J, Szer J, et al. How we mobilize haemopoietic stem cells. Intern Med J, 2011:41(8):588-94.

60. Lie AK, Hui CH, Rawling T, Dyson PG, Thorp D, Benic J, et al. Granulocyte colony-stimulating factor (G-CSF) dose-dependent efficacy in peripheral blood stem cell mobilization in patients who had failed initial mobilization with chemotherapy and G-CSF. Bone Marrow Transplant. 1998;22(9):853-7.

61. Carneiro-Silva FA, Brunetta DM, Kaufman J, Leitão JP, Barroso KS, Barbosa SA, et al. Successful hematopoietic stem cell mobilization with vinorelbine and filgrastim in germ cell tumor. Clin Exp Med. 2016;May 10.Epub ahead of print. 